\title{
Two-dimensional analysis of interaction between deformable hydrofoil and fluid flows in a proplusive stage
}

\author{
$\bigcirc$ 中塚 啓介 (阪大院) 正 竹内 伸太郎（阪大工） \\ 正 梶島 岳夫（阪大工）
}

\begin{abstract}
Keisuke NAKATSUKA, Graduate School of Osaka Univ., Yamadaoka, Suita, Osaka Shintaro TAKEUCHI, Dept. of Mech. Eng., Osaka Univ.

Takeo KAJISHIMA, Dept. of Mech. Eng., Osaka Univ.
\end{abstract}

\begin{abstract}
Numerical simulation of flow past a deformable hydrofoil in a narrow wall is carried out by an arbitrary LagrangianEulerian (ALE) method. The hydrofoil used is NACA0012 and the bottom half of it is oscillated at the amplitude of one fifth the stationary chord length. In this study, the phase difference between deformation and propulsion velocity is observed. It is discussed also in open space. The difference between the propulsion forces is discussed in relation to the strengths and locations of the vortices observed behind the trailing edges.
\end{abstract}

Key Words: Self Oscillation, Fish, Deformable Hydrofoil, Propulsion, Finite Difference Method, ALE Method

\section{1. 緒言}

近年, 新たな推力発生装置への応用を目的として, 魚 類を代表とする生物の推力発生機構の研究が行われてい る.

魚類の推力発生モデルの一つに, 尾びれと体の後半部 分を利用して泳ぐアジ型推進がある．著者らは前報(1) で, 静止状態を初期值として，翼が変形することにより 前進する際の流れ場の解析を行い，発生する後流の渦が 翼の推進におよぼす影響，レイノルズ数依存性について 検討を行った。

本報では，ALE法を用いて，峡险流路内における推進 機構としての変形翼に着比，壁面があることによる後 流渦への影響と推進性能の関係について検討した結果を 示す.

\section{2. 数值解析手法}

本研究では, 流れ場を二次元非圧樎性流体と仮定し た．移動変形する物体周りの流れ場を解析するため, 移 動境界適合座標系を導入する. 物理空間 $(x, y, t)$ を計算 空間 $(\xi, \eta, \tau)$ に写像すると, 変換式は以下のようになる.

$$
\left(\begin{array}{c}
\frac{\partial}{\partial x} \\
\frac{\partial}{\partial y} \\
\frac{\partial}{\partial t}
\end{array}\right)=\left(\begin{array}{lll}
\frac{\partial \xi}{\partial x} & \frac{\partial \eta}{\partial x} & 0 \\
\frac{\partial \xi}{\partial y} & \frac{\partial \eta}{\partial y} & 0 \\
\frac{\partial \xi}{\partial t} & \frac{\partial \eta}{\partial t} & 1
\end{array}\right)\left(\begin{array}{c}
\frac{\partial}{\partial \xi} \\
\frac{\partial}{\partial \eta} \\
\frac{\partial}{\partial \tau}
\end{array}\right)
$$

この関係を連続の式およびNavier-Stokes 式に適用し， $t=\tau$ として以下の式を得る.

$\frac{1}{J} \frac{\partial J U^{j}}{\partial \xi^{j}}=0$

$\frac{\partial u_{i}}{\partial t}+\frac{\partial u_{i}}{\partial \xi^{j}}\left(U^{j}-V^{j}\right)=-\frac{\partial \xi^{j}}{\partial x_{i}} \frac{\partial P}{\partial \xi^{j}}+\frac{1}{R e} \frac{\partial \xi^{j}}{\partial x_{k}} \frac{\partial}{\partial \xi^{j}}\left(\frac{\partial \xi^{l}}{\partial x_{k}} \frac{\partial u_{i}}{\partial \xi^{l}}\right)$

ここで, $U^{j}$ は反変速度, $V^{j}$ は格子の反変移動速度, $t$ は 時間, $p$ は圧力, Reはレイノルズ数である.

時間進行には部分段階法を用いた。空間差分はコロ ケート格子を用いた 2 次精度中心差分, 対流項, 粘性項 及び翼の加速度に 2 次の Adams-Bashforth法を用いて時 間発展させた。

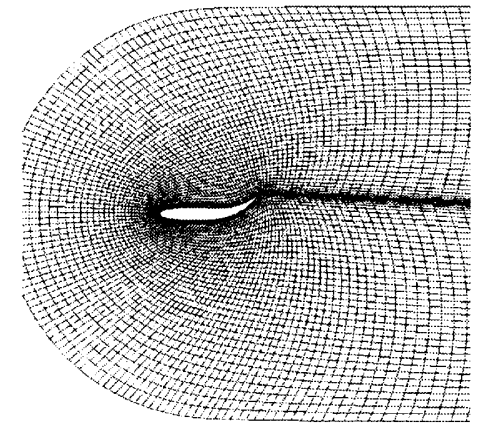

Fig. 1: Computational grid in open space

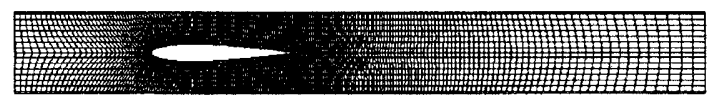

Fig. 2: Computational grid in narrow channel

基本となる翼型にはNACA0012 翼型を用いた。格子 は壁面がないケースは C型境界適合座標(図1) を用い, 格子は $\xi, \eta$ 方向にそれぞれ 320,40 点取った. 壁面がある ケースはH型境界適合格子(図 2)を用い, 格子は $\xi, \eta$ 方向 にそれぞれ 420,30点取った. どちらのケースも翼表面に 160 点の格子数をとった。計算領域は, 翼弦長 $L$ に対し て, 壁面がないケースは半円部分半径を $2 L$, 後流部分を $4 L$ と設定した．また壁面があるケースは翼前方 $L, \mathrm{y}$ 方 向 $0.3 L$, 後流部分を $3 L$ と設定した. 物体の密度比は 2.0 とした，Reは，翼弦長 $L$ と無次元時間 1 に $L$ だけ推進す る速度を基準として定めた。翼は前半部分は変形せず, 後半部分のみを変形させる. 翼表面の点 $(x, y)$ の変形を $\mathrm{x}>\mathrm{L} / 2$ に対して以下の関数で与える.

$$
\begin{aligned}
& x=x_{0} \cos \left\{x_{0} / L \sin \left(2 \pi t^{*}\right)\right\} \\
& y=y_{0}+A\left(t^{*}\right) x_{0} \sin \left\{x_{0} / L \sin \left(2 \pi t^{*}\right)\right\} \\
& A\left(t^{*}\right)=\frac{a\left\{1-\exp \left(-t^{*}\right)\right\}}{L / 2 \cdot \sin (L / 2)} \quad(a=0.2)
\end{aligned}
$$

ここで, $\left(x_{0}, y_{0}\right)$ は図 3 に示すような無変形時の翼弦中 心 $C$ からの位置べクトルである．振幅 $A\left(t^{*}\right)$ は時間とと 


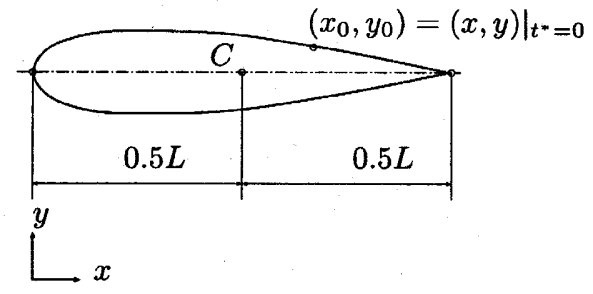

Fig. 3: Schematic of deformable hydrofoil

もに翼弦比の 0.2 倍に漸近するようにした。これは実際 の魚(アジ型)の尾びれの動きに近いと報告されている (2). 式(2),(3)によれば, 変形の 1 周期の体積変化率は $3 \%$ 以内であった。

速度の境界条件としては, 物体表面および壁面に nonslip 条件，流入側に速度ゼロ，流出境界に自由流出を用 いた．圧力の境界条件には，流入・流出で Neumann 条 件, 物体表面では加速度を考慮し, 移動境界とそれに交 差する座標軸との非直交性を補正した条件を用いた ${ }^{(3)}$.

翼が受ける推力 $F_{x}$ は進行方向のみを考慮し, 翼周り の圧力と, 粘性応力から求め, 翼の重心 $T_{x}$ は次の運動方 程式により推進させた.

$$
\ddot{T}_{x}=F_{x} / m
$$

ここで， $m$ は無次元質量である. 本計算で用いたALE法 と数值解析法の組み合わせは, 別途行われた比較計算に より，十分な精度が得られることを確認している(1)。

\section{3. 計算結果}

図 4 は, 推進速度の時間変化を比較している. 負の速 度は図 3 で翼が左方向に運動していることを意味する。 また, 翼後端の $y$ 方向変位の時間変化も同時に示した. 図より, 翼の変位と推進速度には位相差が確認できる. 位相差は, 壁面の有無にかかわらず約 0.1 周期である.

図 5 は時刻 $t^{*}=1.18$ における瞬時の速度べクトルを比 較したものである. 翼の後縁は $y$ 方向に運動中で，振幅 のおよそ60\%に達した瞬間である. 図5(a)では，速度べ クトルを各方向とも 1 格子おきに描いている. 図より, 放出される渦は，壁面がない場合の方がより下流に配置 されているのがわかる.これは, $t^{*}=1.1$ から 1.18 の間の 推進速度の差と対応していると考えられる。

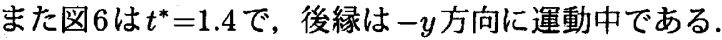
図6(a)は，速度べクトルを各方向とも1格子扝きに描い ている．翼の変形により放出される渦の回転方向は，先 に放出された渦とは逆転しており，逆カルマン渦の配置 となっている.これは, 推進力を発生する渦の配置であ ることがわかる(4).これらの二つの渦の間には増速流が 生じている，壁面がある場合の流れ場では，あらかじめ 放出されていた渦がやや上流にあるため，壁面がない場 合に比べて增速流がより水平に放出されている. 壁面が ある場合の方が，この流れによる推進力は大きいと考え られる.

\section{4. 結言}

本研究では，魚を模擬した変形翼を用い，峡险流路内 で運動する際の流れ場の解析を行った．また壁のない場 合との比較を行うことで以下のような結果を得た。

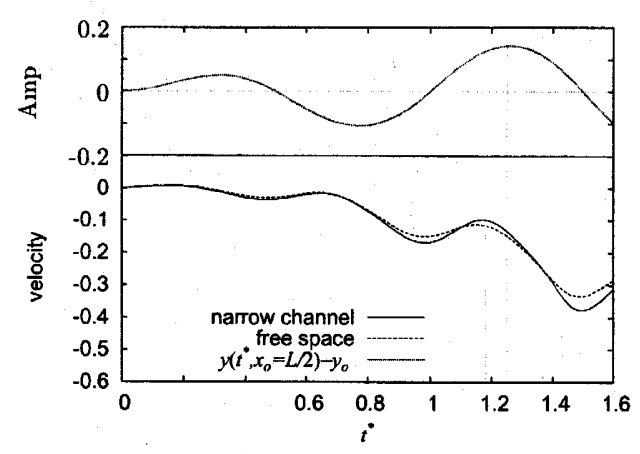

Fig. 4: Time evolution of propulsion velocities

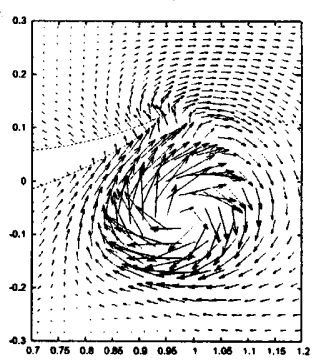

(a) narrow channel

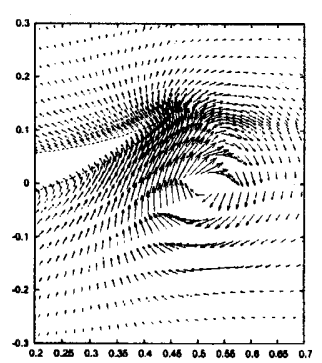

(b)open space
Fig. 5: Instantaneous velocity fields near trailing edge at $t^{*}=1.18$

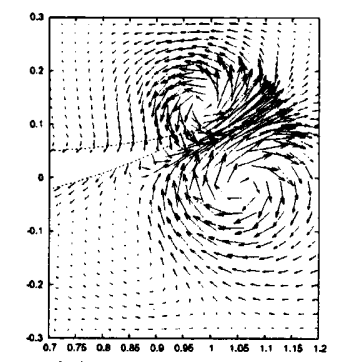

(a) narrow channel

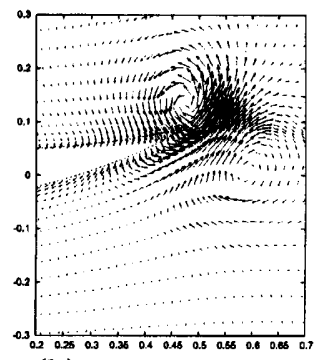

(b)open space
Fig. 6: Instantaneous velocity fields near trailing edge at $t^{*}=1.4$

(1)自由空間中と峓险流路内の推進では，翼の変位と 推進速度の時間変化にはほぼ同じ位相差が見られた。

(2) 峡险流路内で発生した逆カルマン渦対は, 自由空 間で発生したものに比べて，渦中心が上流にある.この ため, 渦間の増速流がより水平に放出され，この過程で 翼はより強い推力を進行方向に受ける。

\section{文献}

(1) 中塚ら, 静止流体中で変形運動する翼の推進モード 解析, 第18回数值流体力学シンポ，E6-1(2004)

(2) Bainbridge, R., The speed of swimming of fish as related to the size and to the frequency and amplitude of the tail beat, J.Exp.Biol. 35, (1958),109-133

(3) 泉ら, 移動境界を含む流動解析の研究, 日本機械学 会論文集(B編)，68，572，(1994),1218-1225

(4) 㴊脇ら,ピッチング/ヒービング運動翼後流の渦構造 と非定常推進力特性，機講論 (流体工学部門)，529, (2004) 